\title{
Effect of Morphine and Nalmefene on Energy Balance in Diabetic and Non-Diabetic Rats
}

\author{
A S LEVINE, ${ }^{1}$ M. GRACE, C. J. BILLINGTON, B. A. GOSNELL, \\ D. D KRAHN, D. M. BROWN AND J. E. MORLEY
Neuroendocrine Research Laboratory, VA Medical Center and Departments of Food Sclence and Nutrition Medicine and Laboratory Medicine and Pathology, University of Minnesota, St Paul-Minneapolis, MN Department of Physiology, University of Texas Health Science Center, Dallas, TX Department of Psychiatry, University of Michigan, Ann Arbor, MI and Geriatric Research, Education and Clinical Center, VA Medical Center, Sepulveda, CA

Received 4 June 1987

\begin{abstract}
LEVINE, A S, M GRACE, C J BILLINGTON, B A GOSNELL, D D KRAHN, D M BROWN AND J E MORLEY Effect of morphine and nalmefene on energy balance in diabetic and non-diabetic rats PHARMACOL BIOCHEM BEHAV 29(3) 495-500, 1988 - Male rats made diabetıc by intravenous injection of streptozotocin were used to evaluate the effect of the diabetic state on morphine- and nalmefene-induced changes in food intake and body weight Morphine increased 4 hour food intake in non-diabetıc rats after an initial injection, but increased intake in diabetic rats only after repeated injections Unlike short term measurements, morphine decreased food intake when measured over 24 or more hours in both groups Chronic injection of morphine decreased body weight only in non-diabetic rats Feed efficiency data suggest that morphine had a more potent effect on energy balance in the non-diabetic rats The opioid antagonist, nalmefene, did not alter body weight in either group and only altered food intake in the diabetic anımals These data are in concert with other reports indicatıng that the diabetic state renders anımals less responsive to the effects of morphine on nociception and smooth muscle contraction
\end{abstract}

Opıolds Diabetes Morphıne Nalmefene

GLUCOSE has been shown to modulate the responsiveness of laboratory anımals to opioid effects In 1956 Davis et al [3] found that hypoglycemia potentiated the antinociceptive action of morphine in rats as quantified by the tail flick method Simon et al $[29,30]$ demonstrated that the analgesic effects of morphine, phenazocine and levorphanol were decreased in rats made diabetic by injection of streptozotocin Pretreatment with hypertonic dextrose or fructose produced the same effect $[29,30]$ Shook et al [28] also reported that increasing the concentration of glucose in the media reduced the responsivity of the electrically stimulated ileum to normorphine which suggests that glucose concentration, rather than insulin alteration, is the mediator of their in vivo findings Recently, Shook and Dewey [27] found that diabetic mice were less physically dependent upon morphine than non-diabetıc controls Genetically diabetıc mice display increased tail flick latencies to radiant heat relative to their littermate controls [9] Both diabetic patients and subjects infused with glucose had decreased pain thresholds and pain tolerance [22]
Since it is known that glucose levels or glucose utilization can modulate feeding behavior, that opıoids can stımulate food intake [7,21] and that glucose modulates oproid nociceptive effects, it seems reasonable to believe that glucose might modulate opioid effects on food intake Our laboratory found that both genetically diabetic mice (C57 $\mathrm{BL} / \mathrm{Ks}-\mathrm{db}+/ \mathrm{db}+$ ) and streptozotocin diabetic mice show enhanced sensitivity to naloxone-induced suppression of food intake [6] Rats made hypoglycemic by injection of ınsulın, a procedure that stımulates food intake, are relatıvely insensitive to naloxone diminution of food intake $[5,10]$, however, this may depend upon the environment in which the study is conducted [25] In general, then, it appears that elevated glucose levels potentiate the naloxone effect, although we have found this to be markedly influenced by the animal's environment [8]

Data concerning long term administration of opıoid agonists and antagonists on food intake and body weight are few and confusing Chronic naltrexone infusions decreased food intake in rats fed chow plus a $32 \%$ sucrose solution

'Requests for reprints should be addressed to Allen S Levıne, Ph D, Research Service (151), VA Medical Center, 54th St \& 48th Ave S , Minneapolıs, MN 55417 
better than in those ingesting only chow [16] Repeated injections of a zinc tannate preparation of naloxone decreased food intake only in rats receiving a high fat cafeteria diet [15] In a group of lean and obese Zucker rats, the long-acting optoid antagontst, nalmefene (6-desoxy-6 methylene naltrexone), decreased food intake but only slightly altered body weight $[11,12]$ On the other hand it has been reported that mice gain weight when given naloxone and decrease their food intake after chronic morphine administration [26] In long term studies in humans naltrexone has been shown to slightly decrease or have no effect on body weight $[1,17]$

The effect of chronic administration of opioids and their antagonists on food intake and body weight in diabetic vs non-diabetic rats is not known In the present study we addressed this issue by injecting the opioid agonist, morphine, and the opioid antagonist, nalmefene, in a group of streptozotocin-induced diabetic rats and non-diabetic rats of the same strain for a period of 24 days while measuring food intake and body weight Nalmefene is potent and long lived relative to naloxone and does not possess as much opioid agonıst actıvity as naloxone [4]

\section{METHOD}

Male Sprague-Dawley rats were used for all studies and were housed under standard lighting and temperature cond1tions (12 hour/day artificial light, $7 \mathrm{a} \mathrm{m}$. to $7 \mathrm{p} \mathrm{m}, 25^{\circ} \mathrm{C}$ ) Anımals were given free access to Purına laboratory chow and to water At about 7 weeks of age rats were given an intravenous injection (tall vein) of streptozotocin $(55 \mathrm{mg} / \mathrm{kg}$ in $13 \%$ citric acid buffer. $\mathrm{pH} 45$ ) followed by $2 \mathrm{ml}$ of $30 \%$ dextrose Three weeks later they were bled via the tall vein and glucose was measured using a Beckman Glucose Analyzer (Fullerton, CA) to assure a diabetıc state (glucose $=632 \pm 22 \mathrm{mg} / \mathrm{dl}$ ). Age-matched rats were used as non-diabetic controls Food intake and body weight were quantified for 3 days before the start of the experimentation to acclimate the animals to handling and daily interruptions The rats were divided into five groups of ten and 1 group of eleven which allowed for three groups of diabetic and three groups of non-diabetic rats. To enable a balanced design for statistical analysis, one rat was omitted at random from the group containıng eleven rats

On day one of the study a single injection of either morphine sulfate $(10 \mathrm{mg} / \mathrm{kg}$, Elı Lilly and Co.. Indianapolıs, IN), nalmefene $(10 \mathrm{mg} / \mathrm{kg}$, kındly provided by Key Pharmaceut1cals, Inc, Miamı, FL) or vehicle was injected subcutaneously Food intake was then measured at hours 1, 2, 4, 6 and 24. During the ensuing 21 days, rats were injected twice per day at about 0900 and $1600 \mathrm{hr}$ On days 2 and 7 tood intake was again quantified at hours 1, 2, 4 and 6 (only 4 hour data are presented) Food intake and body weight were measured on days $3,5,10,12,15,17,19$, and 22 Food intake was corrected for spillage at each measurement and average daily intake was calculated by dividing the total food intake by the representative time penod (eg grams eaten between (day 3/day 5)/3) Anımals were sacrificed on day 24 following one injection of the appropriate drug and trunk bood was collected for analysis of glucose with a glucose oxidase procedure (Sigma Chemical Co., St Louis, MO)

All data are shown as mean \pm SEM Data were analyzed by analysis of variance (ANOVA) (repeated measures when appropriate). Post-hoc tests (least significant difference procedure-LSD) were only conducted if the overall ANOVA demonstrated an interaction The error term for each posthoc test was calculated by a one factor ANOVA
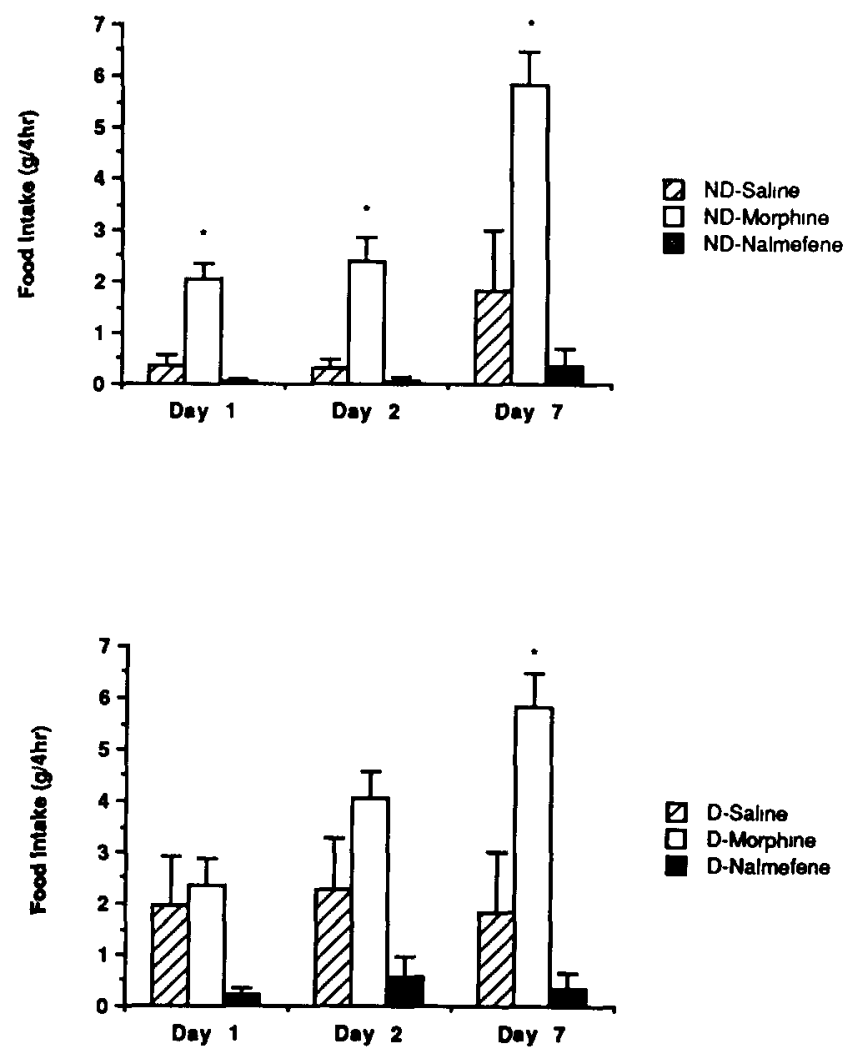

FIG 1 The effect of morphine (10 $\mathrm{mg} / \mathrm{kg} \mathrm{bid})$ and nalmefene (10 $\mathrm{mg} / \mathrm{kg}$ bıd) on 4 hour food intake in diabetıc (D) and non-diabetıc (ND) rats on days 1,2 and 7 of the study $*_{p}<005$ compared to salıne controls for rats of same day and drabetic status

\section{RESULTS}

At sacrifice, trunk blood was sampled and serum was analyzed for glucose concentration Serum glucose levels in diabetic and non-diabetıc animals were not altered following chronic injections of morphine or nalmefene (Diabetic salıne $=530 \pm 14$, morphıne $=496 \pm 2$, nalmefene $=511 \pm 8 \mathrm{mg} / \mathrm{dl}$ ) (Non-Diabetıc salıne $=142 \pm 3$, morphıne $=138 \pm 2$, nalmefene $=148 \pm 5 \mathrm{mg} / \mathrm{dl}$ )

\section{Short-Term Feeding Studies}

The effect of morphine and nalmefene on food intake in diabetic and non-diabetic control rats on day 1 , day 2 and day 7 was analyzed by a 3-factor repeated measures ANOVA There were main effects of diabetic state, $F(1,54)=1172$, of drug, $F(2,54)=2253$, and of day of the study, $\mathrm{F}(2,108)=525$ (all $p$ 's $<001$ ) Also, there was a significant diabetic state $\times$ drug $\times$ day interaction Individual group comparisons (LSD procedure) indicated that morphine stimulated 4 hour food intake in the non-diabetic rats on days 1,2 , and 7 , whereas morphine only stımulated food intake in the diabetic rats on day 7 (Fig 1) Nalmefene had no significant effect on $\mathbf{4}$ hour food intake, although the mean intakes after nalmefene were consistently less than control means Twenty-four hour food intake was significantly decreased in both diabetic and non-diabetic animals following one injection (day 1) and following three injections (day $1+$ day 2) of morphine and nalmefene (Fig 2) 

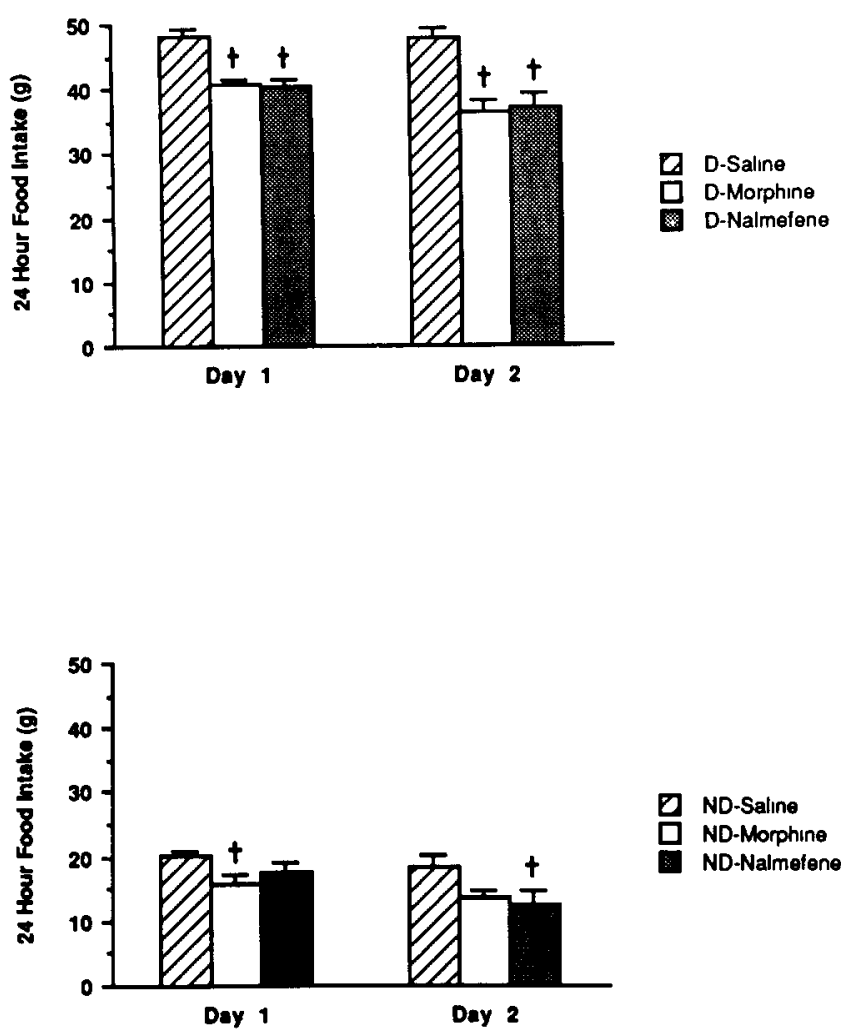

FIG 2 Twenty-four hour food intake in diabetic and non-diabetic rats following morphine $(10 \mathrm{mg} / \mathrm{kg}$ bid) and nalmefene $(10 \mathrm{mg} / \mathrm{kg}$ bid) injections on days 1 and 2 of the study $t p<005$ compared to salıne controls for rats of same day and diabetic status

\section{Chronic Drug Studies}

The effect of morphine and nalmefene on average food intake and on body weight change over 22 days was analyzed by a 3-factor repeated measures ANOVA There were main effects of diabetic state, $F(1,54)=84693$, of drug, $F(2,54)=$ 9.34 , and of day, $\mathrm{F}(7,378)=3916$ (all $p$ 's $<0001$ ). There was a significant diabetic $\times$ drug interaction, $F(2,54)=522$, $p<005$, and a significant diabetic $\times$ drug $\times$ day interaction, $F(14,378)=286, p<0001$ One factor ANOVA followed by LSD tests indicated that food intake was decreased by nalmefene and morphine in the diabetic rats, whereas only morphine decreased feeding at some time points in the nondiabetic control rats (Fig. 3)

Analysis of body weight data demonstrated main effects of diabetic state, $F(1,54)=7842, p<0001$, and of day $\mathrm{F}(8,432)=6385, p<0.001$, but not of drug There was a significant interaction of diabetic state $\times$ drug $\times$ day, $\mathrm{F}(16,432)=1.814, p<0.05$. One factor ANOVA followed by the least significance difference test indicated that body weight was reduced due to morphine injection only in the non-diabetıc anımals (Fig. 4) Nalmefene falled to alter mean body weight in either group of rats Analysis of maximum percent body weight gain (maxımum weight gain or at least a negatıve weight change/initial body weight $\times 100$ ) and maximum percent body weight loss (maximum weight loss or at least a negative weight change/mitial body weight $\times 100$ ) substantiated the observation that morphine has a more potent effect in non-diabetic controls compared with diabetic rats (Fig. 5) In the non-diabetic rats the maximum percent body

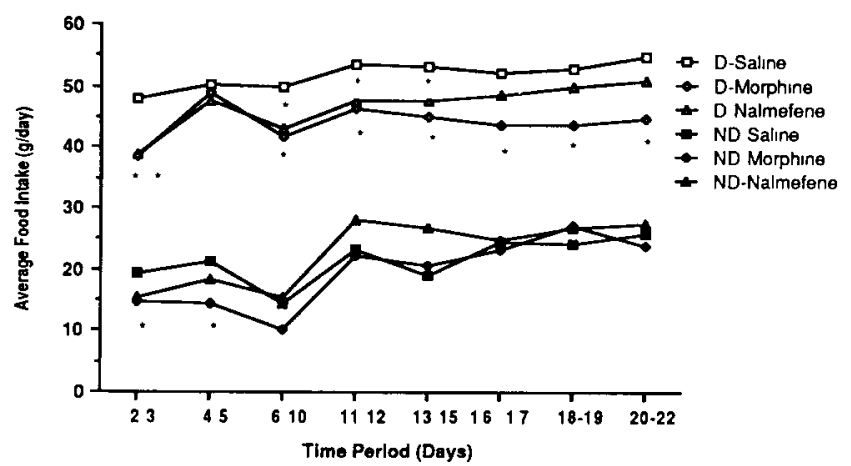

FIG 3 The effect of chronic injection of morphine $(10 \mathrm{mg} / \mathrm{kg}$ bid) and nalmefene $(10 \mathrm{mg} / \mathrm{kg}$ bid) on average food intake in diabetic (D) and non-diabetıc (ND) rats ${ }^{*} p<005$ compared to salıne controls for rats of same day and diabetic status

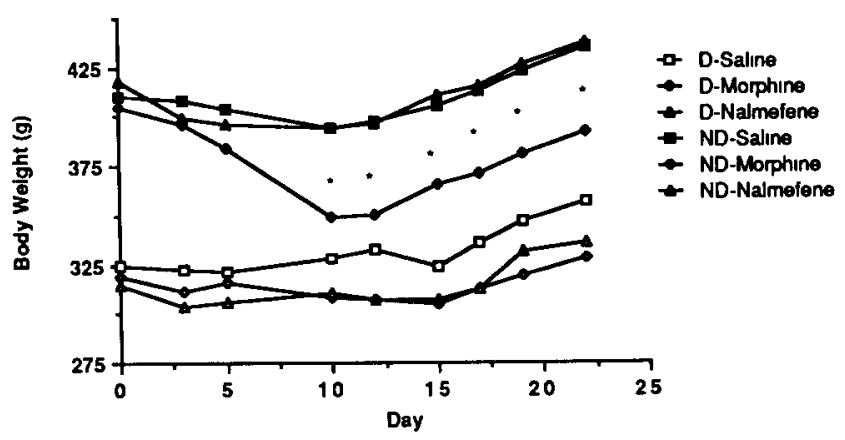

FIG 4 The effect of chronic injection of morphine $(10 \mathrm{mg} / \mathrm{kg})$ and nalmefene $(10 \mathrm{mg} / \mathrm{kg})$ on body weight in diabetic (D) and nondiabetic (ND) rats $*_{p}<005$ compared to saline controls for rats of same day and diabetic status

weight lost by the rats treated with morphine was approximately $15 \%$, in contrast to only above a $5 \%$ maximum body weight loss in the diabetic rats

To integrate food intake and body weight data we calculated a "feed efficiency ratı" (change in body weight [either $(+)$ weight gain or (-) weight loss] from day 0 divided by the cumulative amount of food eaten) Morphine decreased the feed efficiency ratio in diabetics as well as non-diabetics, but had a more potent effect in the non-diabetic group (drug $\times$ diabetic state interaction $F(2,54)=3432, p<0.05$ (Fig. 6) In contrast, nalmefene falled to alter the feed efficiency ratio in non-diabetics, but did so in the diabetics

\section{DISCUSSION}

This study indicates that diabetic rats respond differently than non-diabetic control rats to the acute effects of morphine on food intake as well as to the changes in food intake and body weight which occur following chronic morphine administration Morphine failed to stımulate short term food intake in diabetic anımals following an initial exposure, whereas morphine stımulated feeding in non-drabetic controls rats after a single injection This might be secondary to the increased basal intake of food in the diabetics since opıoids are less potent stımulators of feeding in anımals chronically food deprived [19] or during the nocturnal feeding period [22]. However, repeated exposure of diabetic 

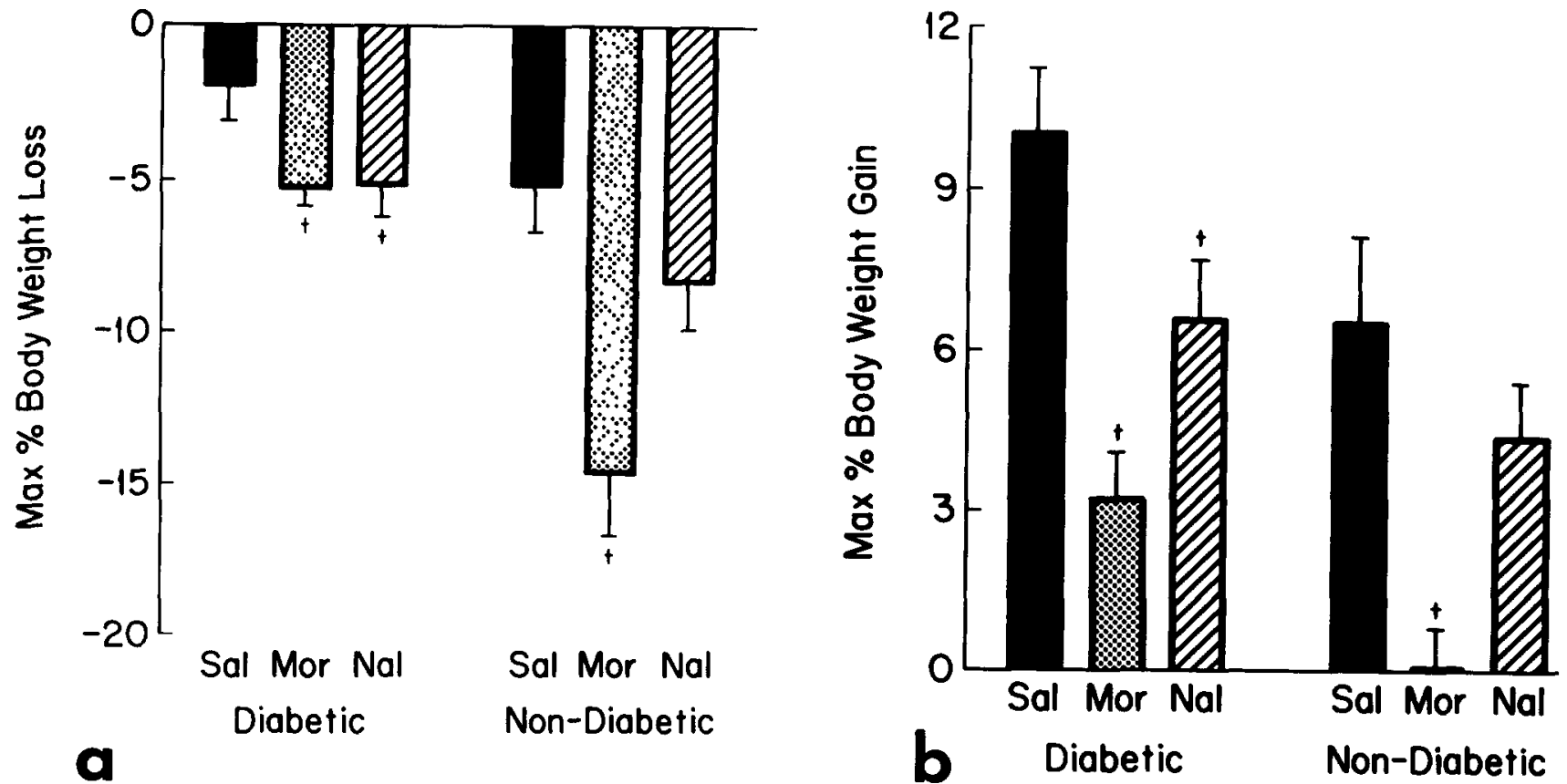

FIG 5 Maxımum percent body weight loss (a) and percent body weight gaın (b) in diabetıc and non-diabetıc rats following chronıc injection of morphine $(10 \mathrm{mg} / \mathrm{kg}$ bıd $)$ and nalmefene $(10 \mathrm{mg} / \mathrm{kg}$ bıd $)+p<005$ compared to salıne controls for rats of same day and diabetıc status

anımals to morphine ultımately resulted in enhanced food intake We have previously reported this "reversetolerance" effect in normal anımals [22] Nalmefene falled to alter short term food consumption in either group of rats, probably due to a floor effect In contrast to the short term studies, chronic administration of morphine to both diabetic and non-diabetic rats resulted in decreased cumulative food intake Also, morphine resulted in a more marked decrease in body weight in the non-diabetic anımals The feed efficiency ratios also substantiated the latter finding, suggesting that diabetic rats were somewhat resistant to morphine's effect on energy balance

The above data are in concordance with those reported by Simon and his colleagues $[29,30]$ They found that streptozotocin-induced diabetic rats were less sensitive to the antinociceptive effects of morphine Recent data from the same laboratory indicates that hyperglycemia modifies the responses of guinea pig ileum and mouse vas deferens responses to normorphıne [4,5] Prelımınary studies [31] Ind1cate that glucose can enhance the binding of naloxone to brain membranes It has also been shown that diabetic humans display decreased pain thresholds and pain tolerance [22] In general, it appears that diabetic anımals respond differently to the effects of morphine on both pain and food intake when compared to non-diabetic control anımals

Relatively few studies have examined the effect of chronic admınıstration of opıoid agonısts or antagonısts on food intake and body weight In our study the long-acting opioid antagonist, nalmefene, failed to alter body weight in either diabetic or non-diabetic rats Nalmefene did not decrease food intake in the non-diabetic rats, but did decrease food intake slightly in the diabetic rats McLaughlin and Barle [11] found that nalmefene decreased meal size and daily food intake, but increased meal frequency in Zucker rats and their lean littermates Body weight decreased during the first week of the study in the nalmefene treated anımals compared with the salıne treated controls, however, subse- quent weight gain was greater in the nalmefene treated rats The weight loss was more marked in the obese Zucker rats Thus, McLaughlın and Barle [11] found only slight effects of nalmefene on body weight Naltrexone, when given twice a day at $10 \mathrm{mg} / \mathrm{kg}$ to genetically obese (ob/ob) mice decreased the rate of weight gain in these obese mice but had no effect on their lean littermates [23] From the latter studies it seems that op1oid antagonism seems to affect energy balance more readily in obese anımals Similarly, it appears that opıod antagonism is more potent in anımals fed palatable foods Repeated injections of a zinc tannate preparation of naloxone abolishes diet-induced obesity in rats fed a high fat cafeterna diet, whereas no effect of opıoid blockade was noted in rats fed a low fat diet [15] Chronic naltrexone infusions $(200 \mu \mathrm{g} / \mathrm{kg} / \mathrm{hr})$ decreased appetite more effectıvely in rats fed chow plus $32 \%$ sucrose compared to those fed chow alone [16] Brands et al [2] also found that a zınc tannate salt of naloxone only decreased food intake during the first few days of the study and body weight during the first ten days of the study

Shimomura et al [26] reported that lean mice given daily morphine injections decreased food intake McLaughlin and Balle [12] reported that rats autoimmunized against $\beta$-endorphin increase both their food intake and body weight This suggests that chronically avalable endogenous $\beta$-endorphin might result in a decrease in food intake and body weight This finding is in keeping with our previous study showing that peripherally infused beta-endorphin decreased food intake [18] The present study indicates that normal rats chronically treated with morphine lose weight and ingest somewhat less food suggestıng that morphine's effect on body weight could be due to increased energy expenditure, rather than secondary to its effects on feeding Also, nalmefene falled to decrease body weight in diabetic anımals, although food intake was decreased However, it is difficult to generalize these effects of morphine and/or $\beta$-endorphin to all opioids 

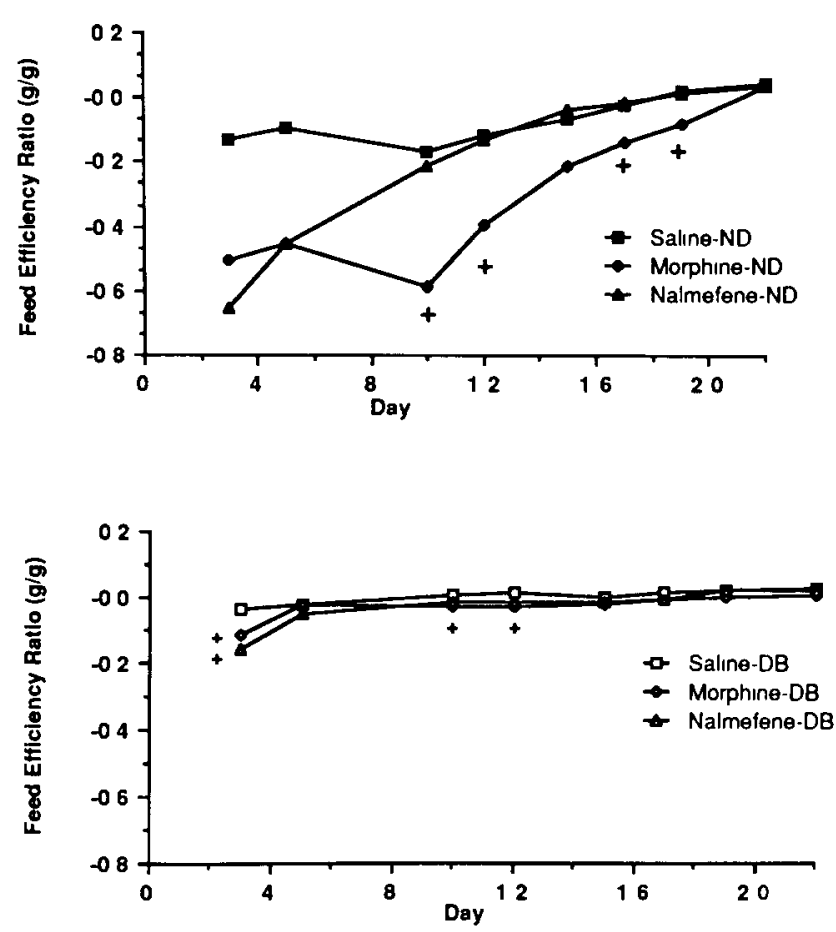

FIG 6 The effect of chronic admınıstration of morphıne $(10 \mathrm{mg} / \mathrm{kg}$ bid) and nalmefene ( $10 \mathrm{mg} / \mathrm{kg}$ bid) on feed efficiency in diabetic and non-diabetic rats $+p<005$ for rats of same day and diabetic status
The decreased feed efficiency noted with chronic injectıon of morphine suggests an effect on energy conservation Morphine seems to have decreased body weight to a greater extent than can be accounted for by food intake alone, particularly in the non-diabetic animals Chronic naloxone injection has been reported by several investigators to increase oxygen consumption $[14,15]$ However, Marks-Kaufman et al [16] found that although naltrexone treatment altered the respiratory quotient, it had no effect on total oxygen consumption Opıoids are also known to affect lipıd metabolism For example, Richter et al [24] demonstrated that $\beta$-lipotropın stımulated lipolysıs in rabbits

Thus, the present data indicate that morphine, when injected chronically, can alter body weight The effect of morphine on body weight is different in diabetic anımals when compared to non-diabetic controls In general, diabetic anımals appear to be less sensitive to the acute effects of morphine on food intake and the effects of chronic administration of morphine on body weight

\section{ACKNOWLEDGEMENTS}

These studies were supported, in part, by grants from the Veterans Admınıstration Medical Center, the National Institute of Drug Abuse (1RO1-DA 03999-01) and the National Institutes of Health (DK-17697) We thank JoAnn Tallman for preparatıon of this manuscript

\section{REFERENCES}

1 Atkınson, $\mathbf{R}$ L, L K Berke, C $\mathbf{R}$ Drake, M L Bibbs, F L Williams and D L Kaiser Effects of long-term therapy with naltrexone on body weight in obesity Clin Pharmacol Ther 38. 419-422, 1985

2 Brands, B, J A Thornhill, M Hirst and C W Gowdey Suppression of food intake and body weight gain by naloxone in rats Life $S_{C l}$ 24: 1773-1778, 1979

3 Davis, W M , T S Miya and L D Edwards The influence of glucose and insulın pretreatment upon morphine analgesia in the rat $J$ Am Pharmacol Assoc 45: 60-62, 1956

4 Hahn, E F and J Fishman Narcotic antagonists Carbon-6 derivatives of $\mathrm{N}$-substituted noroxymorphones as narcotic antagonists $J$ Med Chem 18: 259-262, 1975

5 Levine, A S and J E Morley Peptidergic control of insulininduced feeding Peptides 2: 261-264, 1981

6 Levine, A S, J E Morley, D M Brown and B S Handwerger Extreme sensitivity of diabetic mice to naloxoneinduced suppression of food intake Phystol Behav 28: 987-989, 1982

7 Levine, A S , J E Morley, B A Gosnell, C J Billıngton and T J Bartness Opıoids and consummatory behavior Brain Res Bull 14: 663-672, 1985

8 Levine. A S, J E Morley, J Kneıp. M Grace and D M Brown Environment modulates naloxone's suppressive effect on feeding in diabetıc and non-diabetıc rats Physiol Behai 34: 391-393, 1985

9 Levine, A S, J E Morley, G Wilcox, D M Brown and B S Handwerger Tail pınch behavior and analgesia in diabetıc mice Physiol Behav 28: 39-43, 1982

10 Lowy, M T, R P Maickel and G K W Yım Naloxone reduction of stress-related feeding $L$ fe $S \mathrm{cl}$ 26: 2113-2118, 1980

11 McLaughlın. C L and C A Bale Nalmefene decreases meal size, food and water intake and weight gain in Zucker rats Pharmacol Biochem Behav 19: 235-240, 1983
12 McLaughlın, C L and C A Balle Food intake and weıght gain of Zucker rats Increased by autommunization against B-endorphin Soc Neuroscl Abstr 10: 1015, 1984

13 McLaughlın, C L, C A Baile, R L Gingerich and M E Michel Influence of nalmefene on energy balance and glucose regulation in Zucker rats Physiol Behav 37: 899-908, 1986

14 Malın, D H , J G Leavell, K Freeman, W C Kinzler and M A Reagan Contınuous infusion of naloxone Effects on behavIor and oxygen consumption Pharmacol Biochem Behav 22: $791-795,1985$

15 Mandenoff, A, M Apfelbaum, F Fumeron and D L Margules Endogenous opiates and energy balance Science 215. 1536-1538, 1982

16 Marks-Kaufman, R, T Balmagiya and E Gross Modıficatıons in food intake and energy metabolism in rats as a function of chronic naltrexone infusions Pharmacol Biochem Behav 20: 911-916, 1984

17 Mitchell, J E . J E Morley, A S Levıne, D Hatsukamı, M Gannon and D Pfohl High-dose naltrexone therapy and dietary counseling for obesity Btol Psychiatry 22: 35-42, 1987

18 Morley, J E and A S Levine Corticotropın releasing factor, grooming and ingestıve behavior Life Scl 31: 1459-1464, 1982

19 Morley, J E, A S Levine, B A Gosnell and C J Billıngton Which opioid receptor mechanism modulates feeding? Appettte 5: 61-68, 1984

20 Morley, J E, A S Levine, M Grace and J Kneıp An investıgation of the role of kappa oplate receptor agonists in the initiation of feeding Life Scl 31: 2617-2626, 1982

21 Morley, J E, A S Levine. G K W Yım and M T Lowy Opioid modulation of appetite Neurosci Blobehar $\operatorname{Rer}$ 7: $281-$ 305,1983 
22 Morley, G K, A D Mooradian, A S Levine and J E Morley Why is diabetic peripheral neuropathy painful' The effect of glucose on pain perception in humans $A m J$ Med 77: 79-82, 1984

23 Recant, L, N R Voyles, M Luciano and C B Pert Naltrexone reduced weight gain, alters " $\beta$-endorphin," and reduces insulın output from pancreatic islets of genetically obese mice Peptides 1: 309-313, 1980

24 Richter, W O . P Kerscher and P Schwandt $\beta$-lipotropın increases ketone body plasma concentration in rabbits Neuropeptıdes 4: 167-173, 1984

25 Rowland, $\mathbf{N}$ and $\mathrm{T}$ J Bartness Naloxone suppresses insulininduced food intake in novel and familar environments, but does not affect hypoglycemia Pharmac ol Biochem Behav 16: 10011003,1982

26 Shımomura, Y , J Oku, Z Glıck and G A Bray Opıate receptors, food intake and obesity Physiol Behav 28: 441-443, 1982
27 Shook, J E and W L Dewey Morphine dependence and diabetes I The development of morphine dependence in streptozotocin-diabetıc rats and spontaneously diabetic C57BL/KsJ mice $J$ Pharmacol Exp Ther 237: 841-847, 1986

28 Shook, J E, J F Kachur, D A Brase and W L Dewey Morphine dependence and diabetes II Alterations of normorphine potency in the guinea-pig lleum and mouse vas deferens and of tleal morphine dependence by changes in glucose concentration $J$ Pharmacol Exp Ther 237: 848-852, 1986

29 Simon, G S, J Borzelleca and W L Dewey Narcotics and diabetes II Streptozotocin-ınduced diabetes selectively alters the potency of certain narcotic analgesics Mechanism of diabetes Morphine interaction J Pharmacol Exp Ther 218: 324 329,1981

30 Simon, G S and W L Dewey Narcotics and drabetes I The effects of streptozotocin-induced diabetes on antınociceptive potency of morphıne J Pharmacol Exp Ther 218: 318-323, 1981

31 Werther, G A and A Hogg Abstract from The Neural and Metabolic Bases of Feeding, a symposium presented by the Unıversıty of Calıfornıa, Davis, Napa Valley, CA, 1984, p 16 